\title{
Expression of glycogen synthase and phosphofructokinase in muscle from Type 1 (insulin-dependent) diabetic patients before and after intensive insulin treatment
}

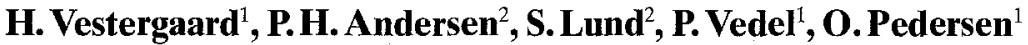 \\ ${ }^{1}$ Steno Diabetes Center and Hagedorn Research Institute, Copenhagen, Denmark \\ ${ }^{2}$ Division of Endocrinology and Metabolism, University Clinic of Internal Medicine C, Aarhus Amtssygehus, Aarhus, Denmark
}

Summary The aim of the present study was to determine whether short-term appropriate insulinization of Type 1 (insulin-dependent) diabetic patients in longterm poor glycaemic control $\left(\mathrm{HbA}_{1 \mathrm{C}}>9.5 \%\right)$ was associated with an adaptive regulation of the activity and gene expression of key proteins in muscle glycogen storage and glycolysis: glycogen synthase and phosphofructokinase, respectively. In nine diabetic patients biopsies of quadriceps muscle were taken before and 24-h after intensified insulin therapy and compared to findings in eight control subjects. Subcutaneous injections of rapid acting insulin were given at 3 -h intervals to improve glycaemic control in diabetic patients (fasting plasma glucose decreased from $20.8 \pm 0.8$ to $8.7 \pm 0.8 \mathrm{mmol} / 1$ whereas fasting serum insulin increased from $59 \pm 8$ to $173 \pm 3 \mathrm{pmol} / \mathrm{l})$. Before intensified insulin therapy, analysis of muscle biopsies from diabetic patients showed a normal total glycogen synthase activity but a $48 \%$ decrease $(p=0.006)$ in glycogen synthase fractional velocity $(0.1 \mathrm{mmol} / \mathrm{l}$ glucose 6-phosphate) $\left(\mathrm{FV}_{0.1}\right)$ and a $45 \%$ increase $(p=0.01)$ in the half-maximal activation constant of glycogen synthase $\left(\mathrm{A}_{0.5}\right)$. The activity of phosphofructokinase and the specific mRNA and immunoreactive protein levels of both glycogen synthase and phosphofructokinase were similar in the two groups. The 2.8 -fold increase in serum insulin levels and the halving of the plasma glucose level for at least $15 \mathrm{~h}$ were associated with a normalization of glycogen synthase fractional activity $\left(\mathrm{FV}_{0.1}\right)$ and of the half-maximal activation constant $\left(A_{0.5}\right)$ whereas the enzyme activity of phosphofructokinase and the mRNA and protein levels of both glycogen synthase and phosphofructokinase remained normal. In conclusion: 1) Reduced allosterical activation of glycogen synthase in muscle of Type 1 diabetic patients in poor metabolic control occurs in the presence of normal total activity as well as normal immunoreactive protein mass and mRNA level of glycogen synthase. 2) Changes in serum insulin within the physiological range play no role in the short-term regulation of glycogen synthase mRNA and protein abundance in muscle from Type 1 diabetic patients. [Diabetologia (1994) 37: 82-90]

Key words Type 1 (insulin-dependent) diabetes mellitus, gene expression, skeletal muscle, glycogen synthase, phosphofructokinase, hexokinase.
Insulin-resistant glucose metabolism in skeletal muscle is a characteristic feature of patients with Type 1 (insulin-dependent) diabetes mellitus in poor glycaemic control [1-3]. Insulin resistance in these patients is not a primary but rather a secondary phenomenon that is

Received: 25 March 1993

and in revised form: 26 July 1993

Corresponding author: Dr. H. Vestergaard, Steno Diabetes Center, Niels Steensens Vej 2, DK-2820 Gentofte, Denmark completely reversed during remission of the disease in recent-onset Type 1 diabetes [4] or nearly ameliorated by improved glycaemic control in patients with longterm diabetes $[5,6]$. It has, therefore, been suggested that the insulin resistance in Type 1 diabetes, at least in part, is secondary to metabolic derangements $[3,7]$. Previous studies of the cellular insulin resistance of peripheral tissues from patients with Type 1 diabetes have shown decreased insulin binding to musclederived insulin receptors but normal receptor kinase activity [8] and decreased glucose transport and oxida- 
tion in adipose tissue [9]. Moreover, using the hyperinsulinaemic-euglycaemic clamp in combination with indirect calorimetry a reduced total glucose disposal rate due to reduced non-oxidative as well as reduced oxidative glucose metabolism has been demonstrated in Type 1 diabetes [10].

Approximately $75 \%$ of insulin-regulated whole body glucose clearance takes place in skeletal muscle [11]. Once glucose has been taken up by skeletal muscle it is irreversibly phosphorylated by hexokinase to glucose 6-phosphate (G6P) and routed into either glucose storage as glycogen or glycolysis. Glycogen synthase (GS) is the key enzyme in glycogen synthesis and exists in an active dephosphorylated form and in a less active phosphorylated form [12]. The two forms of the enzyme are interconverted by phosphorylation-dephosphorylation reactions with G6P allosterically activating the phosphorylated form of GS, whereas insulin acts covalently on GS by reducing and increasing the activities of specific kinases and phosphatases, respectively [12]. The decreased glucose clearance of peripheral tissues in Type 1 diabetic patients has been shown to be accompanied by decreased glycogen synthase activity in skeletal muscle $[1,10]$. Phosphofructokinase (PFK) is a rate-limiting enzyme in glycolysis [13] catalysing the transformation of fructose 6-phosphate to fructose-1,6-diphosphate, a process which is allosterically regulated by several metabolites [13] and previous studies in diabetic rodents have shown an impairment of muscle PFK activity [14]. However, no information is available on the function of this enzyme in insulin-dependent diabetes of man [14]. Finally, in a study of glucose-tolerant subjects it was demonstrated that hyperglycaemia caused accumulation of intracellular free glucose indicating that the rate-limiting step in skeletal muscle glucose metabolism in normal man is located at or distal to glucose phosphorylation [15].

Hence, to gain further insight into the abnormal glucose metabolism of skeletal muscle from patients with Type 1 diabetes we have examined whether short-term appropriate insulinization of patients with long-term diabetes in poor glycaemic control is associated with an adaptive regulation of muscle activities as well as immunoreactive protein and mRNA levels of two key proteins in glycogen storage and glycolysis, GS and $\mathrm{PFK}$, respectively.

\section{Subjects and methods}

Subjects. Nine male patients with Type 1 diabetes (age $31 \pm 2$ years, body mass index $23 \pm 1 \mathrm{~kg} / \mathrm{m}^{2}$ ) and eight male control subjects ( $27 \pm 2$ years, body mass index $25 \pm 1 \mathrm{~kg} / \mathrm{m}^{2}$ ) participated in the study. All were Caucasians and had sedentary lifestyles. The control subjects had normal fasting plasma glucose levels, normal blood pressure and no family history of diabetes. Patients with Type 1 diabetes were recruited from the outpatient clinic at the Steno Diabetes Center. The duration of diabetes was $11 \pm 3$ years. The patients had no clinical or bio- chemical signs of long-term diabetic complications but were all in poor glycaemic control with $\mathrm{HbA}_{1 \mathrm{C}}$ greater than $9.5 \%$. None of the participants in the study suffered from liver or kidney disease as evaluated by clinical and standard laboratory examinations, and no subject was taking any other medication which is known to influence carbohydrate and lipid metabolism. All patients were treated with multiple insulin injections using a pen injector (Novopen; Novo Nordisk, Bagsvaerd, Denmark), shortacting insulin (Actrapid; Novo Nordisk) three times daily before main meals and intermediate-acting insulin (Insulatard; Novo Nordisk) at bedtime.

Prior to participation the purpose and risks of the study were carefully explained to all of the volunteers and their informed consent was obtained. The protocol was approved by the local ethical committee and was in accordance with the Helsinki Declaration.

Study protocol. The diabetic patients were admitted to the hospital for $36 \mathrm{~h}$ and continued to consume their usual individualized diet, typically containing as energy $45 \%$ carbohydrate, $40 \%$ fat and $15 \%$ protein. Meals were served as three main meals (breakfast, lunch and dinner) and as three snacks. Besides short distance walks in the hospital, no physical exercise was allowed during the study period. The last injection of insulin was taken before dinner the evening prior to the study. In diabetic patients biopsies of quadriceps muscle were taken in the morning after an overnight fast between 08.00 and 09.00 hours before and $24 \mathrm{~h}$ after intensive insulin therapy. Injections of rapid-acting insulin (Actrapid; Novo Nordisk) were given in the abdominal subcutaneous tissue at 3 -h intervals. On an empirical basis we decided to give $80 \%$ of the preadmission insulin dose for each individual within the first $9 \mathrm{~h}$ of study. In the remaining study period the insulin dose was adjusted to keep the plasma glucose levels within excursions from $5-10 \mathrm{mmol} / \mathrm{l}$. The last dose was given $3 \mathrm{~h}$ prior to the second muscle biopsy. None of the patients experienced hypoglycaemic episodes during the study period.

The control subjects were admitted to the hospital in the morning of the study between 08.00 and 09.00 after a 10 -h overnight fast, and a muscle biopsy and a blood sample were obtained. All study participants were asked to refrain from any major physical activity for $36 \mathrm{~h}$ before the examination.

Muscle biopsies. Percutaneous biopsies (about $400 \mathrm{mg}$ ) were obtained under local anaesthesia (1\% lidocaine without epinephrine) from the vastus lateralis of the quadriceps muscle approximately $20 \mathrm{~cm}$ above the knee, using a modified Bergström needle (Stille-Werner, Copenhagen, Denmark). Muscle samples were blotted to remove blood, connective and adipose tissue and within $30 \mathrm{~s}$ were frozen in liquid nitrogen, and stored at $-80^{\circ} \mathrm{C}$ until assayed.

Determination of glycogen synthase, phosphofructokinase and hexokinase activities. Preparation of muscle samples and assays for GS and analysis of total muscle protein were performed as described previously [16].

Glycogen synthase (GS) activity was assayed in duplicate in the absence or presence of 7 concentrations $(0-6.7 \mathrm{mmol} / \mathrm{l})$ of G6P. Total activity refers to the GS activity in the presence of a saturating concentration of G6P (6.7 mmol/l $)$. The final concentration of uridine diphosphate glucose (unlabelled UDP-glucose + UDP-[U- $\left.{ }^{14} \mathrm{C}\right]$ glucose [New England Nuclear, Boston, Mass., USA]) in the reaction mixture was $0.13 \mathrm{mmol} / 1$. GS activity was expressed as nanomoles UDP-glucose incorporated into glycogen per min per milligramme soluble protein in the homogenate. Fractional velocities (FV) were calculated as GS activity in the presence of subsaturating levels of G6P divided by GS activity in the presence of a saturating concentration of $\mathrm{G} 6 \mathrm{P}$ 
$(6.7 \mathrm{mmol} / \mathrm{l})$. Fractional velocities are thought to reflect the in vivo covalent activation of the enzyme. The concentration of $\mathrm{G} 6 \mathrm{P}$ giving half-maximal stimulation of the $\mathrm{GS}\left(\mathrm{A}_{0.5}\right.$ for $\left.\mathrm{GS}\right)$ was calculated using Hill plot. The inter-assay coefficients of variation were 0.12 for $A_{0.5}$ and 0.13 for total GS, respectively, $(n=6$ separate experiments performed on muscle tissue from the same volunteer).

Phosphofructokinase (PFK) activity in supernatants of muscle extracts was assayed in duplicate spectrophotometrically in the presence of $0.1,0.5$ and $2.0 \mathrm{mmol} / 1$ fructose 6 -phosphate (F6P). The same initial supernatant employed for the GS assay was used for the PFK assay but without dilution. The reaction was initiated by the addition of F6P. The assay coupled the conversion of F6P to fructose 1,6-diphosphate with the oxidation of $\mathrm{NADH}$ by means of a series of enzymatic steps. Enzyme activity was assayed by a modification of the method of Beutler [17] at $22^{\circ} \mathrm{C}$ in a buffer where final concentrations of reaction constituents were ATP $1.2 \mathrm{mmol} / 1, \mathrm{MgSO}_{4}, 1.4 \mathrm{mmol} / 1, \mathrm{KCl} 2.4$ $\mathrm{mmol} / \mathrm{l}, \mathrm{NADH} 0.2 \mathrm{mmol} / \mathrm{l}, 10 \mu \mathrm{l}$ muscle homogenate (or $40 \mu \mathrm{l}$ F6P kinase in a concentration of $33 \mu \mathrm{g} / \mathrm{ml}$ for standard) and auxiliary enzymes in $70 \mathrm{mmol} / 1$ Tris buffer, $\mathrm{pH}$ 8.0. Maximal PFK enzyme activity was calculated using the Michaelis-Menten equation. PFK activity was expressed as nanomoles of F6P converted per min per milligramme of extracted protein. Interassay coefficient of variation was $0.10(n=6$ separate experiments performed on muscle tissue from the same volunteer).

Total hexokinase (HK) activity in supernatants of muscle extracts was assayed in duplicate spectrophotometrically in the presence of $0.11 \mathrm{mmol} / 1$ and $11.0 \mathrm{mmol} / 1$ glucose, respectively, by a modification of the method of Easterby and Qadri [18]. The same initial supernatant employed for the GS assay was used for HK assay but without dilution. The supernatant was assayed at $22^{\circ} \mathrm{C}$ in a buffer containing (final concentrations) $28 \mathrm{mmol} / \mathrm{I}$ Tris$\mathrm{HCl}(\mathrm{pH} 7.6), 17.9 \mathrm{mmol} / 1 \mathrm{MgCl}_{2}, 2.8 \mathrm{mmol} / \mathrm{l}$ EDTA, $0.9 \mathrm{mmol} / \mathrm{l}$ $\mathrm{NADP}^{+}, 0.6 \mathrm{mmol} / 1 \mathrm{ATP}$ and $13.8 \mu \mathrm{g} / \mathrm{ml} \mathrm{G} 6 \mathrm{P}$ dehydrogenase (Boehringer Mannheim, Mannheim, Germany). The G6P produced in the hexokinase reaction is coupled to G6P dehydrogenase. The reaction is followed by measuring the increase in absorbance at $340 \mathrm{~nm}$ due to NADPH formation. HK activity was expressed as nanomoles of glucose converted per min per milligramme of extracted protein. Inter-assay coefficient of variation was 0.10 ( $n=6$ separate experiments performed on muscle tissue from the same volunteer).

To exclude any influence of day-to-day variation, muscle samples from diabetic patients and control subjects were prepared and analysed for GS, PFK and HK enzymes pairwise at the same time.

Isolation and analysis of RNA and DNA. Total RNA from muscle biopsies was isolated as described by Chomczynski and Sacchi [19]. Quantity and purity of RNA was determined by absorbance at 260 and $280 \mathrm{~nm}$. Northern blot analysis was performed to recognize the size of the transcripts of GS and PFK, to ensure specificity of the cDNA probes, to check for background contamination, and to examine if the transcript sizes were affected by diabetes. After denaturation, total RNA was loaded on $1.2 \%$ (volume/volume, v/v) formaldehyde-agarose gels and transferred to and immobilized on nylon membranes (Gene Screen, DuPont, San Francisco, Calif., USA). cDNA probes for human muscle GS (kindly provided by Professor R. J. Fletterick and Dr. M.F. Browner, University of California, San Francisco, Calif., USA) and human muscle PFK (kindly provided by Dr. A. McLachlan, Scripps Clinic \& Research Foundation, La Jolla, Calif., USA) were labelled with ${ }^{32} \mathrm{P}$ by random priming (GS: Prime-a-Gene labelling kit; Promega, Madison, Wis., USA) or nick translation (PFK: Nick Translation System; Promega) and hybridized to nylon filters under stringent conditions [20]. The filters were washed with $0.5 \times \mathrm{SSC}$ (SSC: $0.15 \mathrm{~mol} / 1$ sodium chloride, $0.015 \mathrm{~mol} / 1$ sodium citrate, $\mathrm{pH} 7.0$ ) at $55^{\circ} \mathrm{C}$ before autoradiography. For quantitation of mRNA specific for GS and PFK, a slot-blot apparatus (Bio Dot SF; Bio Rad, Richmond, Calif., USA) was used. The integrity of the RNA used for the slot blotting analysis was controlled on a $0.7 \%$ agarose gel by visual inspection of ribosomal bands stained with ethidium bromide. No signs of degradation were found in any of the samples used for slot blot analysis. Total muscle RNA was applied $(1.0 \mu \mathrm{g} / \mathrm{slot})$ to a nylon membrane and filters were hybridized with the GS and PFK cDNA probes, respectively, as described above. The abundance of GS and PFK mRNA was determined within the linear response range by scanning densitometry (Shimadzu CS 9000 flying spot densitometer; Shimadzu Corp., Tokyo, Japan). The inter-assay coefficient of variation for measurement of both GS and PFK mRNA was 0.07 ( $n=6$ separate studies performed on muscle from the same volunteer). DNA was measured spectrofluometrically [21].

Preparation of GS and PFK antipeptide antibodies. Peptides containing the nine amino acid GS-carboxy-terminus $\left[\left(\mathrm{NH}_{2}\right)\right.$ TSSLGEERN] and the nine amino acid PFK-carboxy-terminus $\left[\left(\mathrm{NH}_{2}\right)\right.$-KRSGSEAAV] were synthesized (Kem-En-Tec, Copenhagen, Denmark) and each coupled to bovine serum albumin using glutaraldehyde. Two millilitres of $0.4 \%(\mathrm{v} / \mathrm{v})$ glutaraldehyde (Sigma G 5882, St. Louis, Mo., USA) in $0.01 \mathrm{~mol} / 1$ phosphate buffer, $\mathrm{pH} 7.2$, were added dropwise to a mixture of $3 \mathrm{mg}$ peptide and $28 \mathrm{mg}$ bovine serum albumin (RIA grade, Sigma A 7888) and dissolved in $4 \mathrm{ml} 0.01 \mathrm{~mol} / \mathrm{l}$ phosphate buffer, $\mathrm{pH}$ 7.2. Stirring was continued for $4 \mathrm{~h}$ at room temperature and overnight at $4^{\circ} \mathrm{C}$, respectively. The product was dialysed against $0.01 \mathrm{~mol} / 1 \mathrm{phosphate,} 0.15 \mathrm{~mol} / \mathrm{l} \mathrm{NaCl}$ buffer, $\mathrm{pH} 7.2$. Two rabbits were immunized by subcutaneous injections on days 0,14 , 28,56 and 84 with $0.1 \mathrm{mg}$ conjugate contained in a volume of $0.5 \mathrm{ml}$ mixed with $0.5 \mathrm{ml}$ adjuvant. The first injection was made with Freund's complete adjuvant and the following with Freund's incomplete adjuvant. The animals were bled on days 35, 63 and 91, and the serum from the two rabbits for each date were pooled. Rabbit immunoglobulin was purified from the serum by precipitation with caprylic acid as described [22].

Immunoblotting. Fifteen to twenty $\mathrm{mg}$ of frozen muscle $(1 \mathrm{mg}$ tissue/20 $\mu$ l buffer) was homogenized with a polytron $(2,000$ $\mathrm{rev} / \mathrm{min}$ ) for $45 \mathrm{~s}$ at $4^{\circ} \mathrm{C}$ in a buffer, $\mathrm{pH} 7.4$, consisting of 25 $\mathrm{mmol} / \mathrm{l}$ Hepes, $10 \mathrm{mmol} / 1 \mathrm{~K}-\mathrm{EDTA}, 100 \mathrm{mmol} / 1 \mathrm{NaF}, 1 \%(\mathrm{v} / \mathrm{v})$ Triton X-100 and $1 \mathrm{mmol} / 1$ Benzamidine, $900,000 \mathrm{kU} / 1$ Trasylol (aprotinin) and $2 \mathrm{mmol} / \mathrm{l}$ phenylmethylsulphonyl fluoride (PMSF). Connective tissue and insoluble cell constituents with no measurable GS or PFK immunoreactivities, were removed from homogenate by centrifugation at $6,000 \mathrm{~g}_{\max }\left(5 \mathrm{~min} ; 4^{\circ} \mathrm{C}\right)$. Samples, $100-200 \mu \mathrm{g}$ of protein per lane, were separated in duplicate on a $10 \%$ SDS-PAGE gel with a $4 \%$ stacking gel. A human muscle protein standard preparation was run on each gel in triplicate and used to correct for inter-gel variations in the immunoblots. Prestained molecular weight markers were from Bio Rad. The proteins were electrophoretically transferred to a $0.45 \mu \mathrm{m}$ nitrocellulose membrane $\left(200 \mathrm{~V}, 4 \mathrm{~h}\right.$ at $0-4^{\circ} \mathrm{C}$, Bio- $\mathrm{Rad}$ High Efficiency Transfer System with Plate Electrons). After blocking with $5 \%$ (weight/volume, w/v) bovine serum albumin, $20 \mathrm{mmol} / 1$ Tris, $500 \mathrm{mmol} / \mathrm{l} \mathrm{NaCl}, \mathrm{pH} 7.5$, for $12-24 \mathrm{~h}$, the membranes were incubated with either GS $(1: 10.000)$ or PFK (1:5000) antisera for $12-24 \mathrm{~h}$ at $4^{\circ} \mathrm{C}$. After washing, blots were incubated with $\left[{ }^{35} \mathrm{~S}\right]$-protein A (Amersham Corp., Arlington Heights, Ill., USA) with a specific activity of $0.2 \mu \mathrm{Ci} / \mathrm{ml}$ buffer for $1 \mathrm{~h}$ at $20^{\circ} \mathrm{C}$. Quantitative scanning of autoradiograms was performed within the linear response range, as determined by standard curves of purified GS and PFK proteins using a Shi- 
Table 1. Glycogen synthase activity in vastus lateralis muscle from study participants

\begin{tabular}{|c|c|c|c|}
\hline & \multicolumn{2}{|c|}{ Type 1 diabetic patients } & \multirow{2}{*}{$\begin{array}{l}\text { Control } \\
\text { subjects }\end{array}$} \\
\hline & Biopsy 1 & Biopsy 2 & \\
\hline $\begin{array}{l}\text { Total activity (nmol. } \\
\text { mg protein } \\
\left.-1 \cdot \min ^{-1}\right)\end{array}$ & $27.82 \pm 1.75$ & $28.64 \pm 1.80$ & $32.89 \pm 2.59$ \\
\hline $\mathrm{FV}_{0.1}(\%)$ & $7.87 \pm 0.89^{\mathrm{a}}$ & $17.19 \pm 3.20^{c}$ & $14.01 \pm 1.51$ \\
\hline $\mathrm{A}_{0.5}(\mathrm{mmol} / \mathrm{l})$ & $0.65 \pm 0.05^{b}$ & $0.40^{\mathrm{b}} \pm 0.06^{\mathrm{c}}$ & $0.45 \pm 0.04$ \\
\hline
\end{tabular}

${ }^{\mathrm{a}} p=0.006$ vs control subjects; ${ }^{\mathrm{b}} p=0.01$ vs control subjects; ${ }^{\circ} p=0.03$ vs biopsy 1 .

Values are given as mean $\pm S E M$.

Total activity refers to the glycogen synthase (GS) activity in the presence of a saturating concentration of glucose 6-phosphate (G6P) (6.7 mmol/l). Fractional velocity $\left(\mathrm{FV}_{0.1}\right)$ was calculated as GS activity in the presence of the physiological concentration of G6P $(0.1 \mathrm{mmol} / \mathrm{l})$ divided by GS activity in the presence of $6.7 \mathrm{mmol} / 1 \mathrm{G} 6 \mathrm{P}$. $\mathrm{A}_{0.5}$ is the $\mathrm{G} 6 \mathrm{P}$ concentration that half maximally stimulates GS

Table 2. Phosphofructokinase (PFK) and hexokinase (HK) activities in vastus lateralis muscle from study participants

\begin{tabular}{|c|c|c|c|}
\hline & \multicolumn{2}{|c|}{ Type 1 diabetic patients } & \multirow{2}{*}{$\begin{array}{l}\text { Control } \\
\text { subjects }\end{array}$} \\
\hline & Biopsy 1 & Biopsy 2 & \\
\hline & \multicolumn{3}{|c|}{$\mathrm{nmol} \cdot \mathrm{mg} \operatorname{protein}^{-1} \cdot \mathrm{min}^{-1}$} \\
\hline $\begin{array}{l}\mathrm{PFK}(0.1 \mathrm{mmol} / 1 \mathrm{~F} 6 \mathrm{P}) \\
\mathrm{PFK}(0.5 \mathrm{mmol} / 1 \mathrm{~F} 6 \mathrm{P}) \\
\mathrm{PFK}(2.0 \mathrm{mmol} / 1 \mathrm{~F} 6 \mathrm{P}) \\
\text { PFK } \mathrm{V}_{\max }\end{array}$ & $\begin{array}{l}232 \pm 11 \\
419 \pm 28 \\
490 \pm 35 \\
523 \pm 39\end{array}$ & $\begin{array}{l}237 \pm 11 \\
424 \pm 23 \\
491 \pm 29 \\
532 \pm 28\end{array}$ & $\begin{array}{l}263 \pm 11 \\
499 \pm 27 \\
587 \pm 53 \\
635 \pm 40\end{array}$ \\
\hline $\begin{array}{l}\mathrm{HK}(0.11 \mathrm{mmol} / 1 \text { glucose }) \\
\mathrm{HK}(11.0 \mathrm{mmol} / \mathrm{l} \text { glucose })\end{array}$ & $\begin{array}{l}5.3 \pm 0.4 \\
7.2 \pm 0.5\end{array}$ & $\begin{array}{l}5.6 \pm 0.3 \\
7.7 \pm 0.6\end{array}$ & $\begin{array}{l}6.3 \pm 0.6 \\
8.9 \pm 0.8\end{array}$ \\
\hline
\end{tabular}

Values are given as mean $\pm \mathrm{SEM}$

F6P, Fructose 6-phosphate

Table 3. Characteristics of tissue from vastus lateralis muscle from study participants

\begin{tabular}{lccc}
\hline & \multicolumn{2}{c}{ Type 1 diabetic patients } & \multirow{2}{c}{$\begin{array}{c}\text { Control } \\
\text { subjects }\end{array}$} \\
\cline { 2 - 3 } & Biopsy 1 & Biopsy 2 & \\
\hline DNA/g tissue $(\mu \mathrm{g} / \mathrm{g})$ & $962 \pm 24^{\mathrm{a}}$ & $1040 \pm 58$ & $1087 \pm 50$ \\
RNA/g tissue $(\mu \mathrm{g} / \mathrm{g})$ & $492 \pm 39$ & $523 \pm 35$ & $474 \pm 27$ \\
RNA/DNA $(\mu \mathrm{g} / \mu \mathrm{g})$ & $0.51 \pm 0.04$ & $0.51 \pm 0.03$ & $0.45 \pm 0.04$ \\
Protein/g tissue $(\mathrm{mg} / \mathrm{g})$ & $78.4 \pm 2.7^{\mathrm{b}}$ & $81.1 \pm 3.9$ & $89.5 \pm 2.3$ \\
Protein/ $(\mathrm{mg} / \mu \mathrm{g}) \mathrm{DNA}$ & $81.7 \pm 2.4$ & $80.9 \pm 7.8$ & $83.5 \pm 4.6$ \\
(mg/ $\mu \mathrm{g})$ & & & \\
\hline
\end{tabular}

${ }^{\mathrm{a}} p=0.03$ vs control; ${ }^{\mathrm{b}} p=0.01$ vs control subjects.

Values are given as mean $\pm S E M$

madzu CS 9000 flying spot densitometer. Studies of the immunoreactivity of GS or PFK in muscle specimens from Type 1 diabetic patients and control subjects were run in parallel at the same time. When six different samples from the same muscle biopsy were analysed the inter-assay coefficient of variation was 0.11 for both GS and PFK.

The specificity of the antisera were tested against purified GS (Sigma G 2259) and F6P kinase (Sigma F 6877) isolated from rabbit skeletal muscle. Each antiserum produced a single band with a molecular weight of $84 \mathrm{kDa}$ and $85 \mathrm{kDa}$, respectively. Ab- sorption of the antisera with peptides used for immunization of rabbits resulted in complete disappearance of the bands at $84 \mathrm{kDa}$ and $85 \mathrm{kDa}$, respectively.

Other analytical determinations. Glucose in plasma was measured by a hexokinase method [23]. Serum insulin and C-peptide concentrations were analysed by RLA $[24,25]$. Insulin in serum was measured after precipitation with polyethylene gly$\mathrm{col} . \mathrm{HbA}_{1 \mathrm{C}}$ was measured by isoelectric focusing [26], normal range $4.1-6.1 \%$. Non-esterified fatty acids (NEFA) in plasma were determined by the method of Itaya and Micho [27].

\section{Statistical analysis}

Statistical analysis was performed with the SPSS package (Statistical Package for the Social Sciences). Non-parametric statistics were used: Mann-Whitney test for unpaired data and Wilcoxon test for paired data and Spearman's test for correlation analysis. $P$ values less than 0.05 were considered significant. All data in text and figures are given as mean \pm SEM.

\section{Results}

\section{Characterization of subjects}

At entry into the study the diabetic patients were all in poor metabolic control with a mean $\mathrm{HbA}_{1 \mathrm{C}}$ level of $10.3 \%$ (range $9.5-11.2 \%$ ) and a significantly higher fasting plasma glucose level compared to that of control subjects $(20.8 \pm 0.8$ vs $5.3 \pm 0.1 \mathrm{mmol} / 1, p=0.0006)$. Fasting serum insulin levels were similar to those of control subjects $(59 \pm 8$ for diabetic patients vs $50 \pm 7 \mathrm{pmol} / \mathrm{l}$ for control subjects, NS).

The mean daily dose of insulin before entering the study was $54 \pm 5 \mathrm{IU} / 24 \mathrm{~h}$ and during the day of intensive therapy $65 \pm 4 \mathrm{IU} / 24 \mathrm{~h}(p<0.05)$. Intensified insulin therapy in the diabetic patients increased fasting serum insulin levels significantly from $59 \pm 8$ to $173 \pm 3 \mathrm{pmol} / 1(p<0.01)$ and decreased fasting plasma glucose levels from $20.8 \pm 0.8$ to $8.7 \pm 0.8 \mathrm{mmol} / 1$ $(p<0.01)$ and fasting plasma levels of NEFA from $1.38 \pm 0.18$ to $0.41 \pm 0.05 \mathrm{mmol} / 1(p<0.01)$. Serum insulin and plasma glucose levels after intensive therapy were both significantly higher in diabetic patients than in control subjects $(p<0.001$ and $p<0.005$, respectively).

\section{Glycogen synthase, phosphofructokinase and hexokinase activities}

GS activity. Total GS activity, i.e. in the presence of a maximal concentration of the allosterical activator G6P, was not different between patients and control subjects (Table 1). The fractional velocity of GS at the physiological $\mathrm{G} 6 \mathrm{P}$ concentration of $0.1 \mathrm{mmol} / 1\left(\mathrm{FV}_{0.1}\right)$ was decreased by $48 \%(p=0.006)$ in patients before intensive insulin therapy when compared to control subjects. Intensified insulin therapy for 24 h caused a significant in- 
A
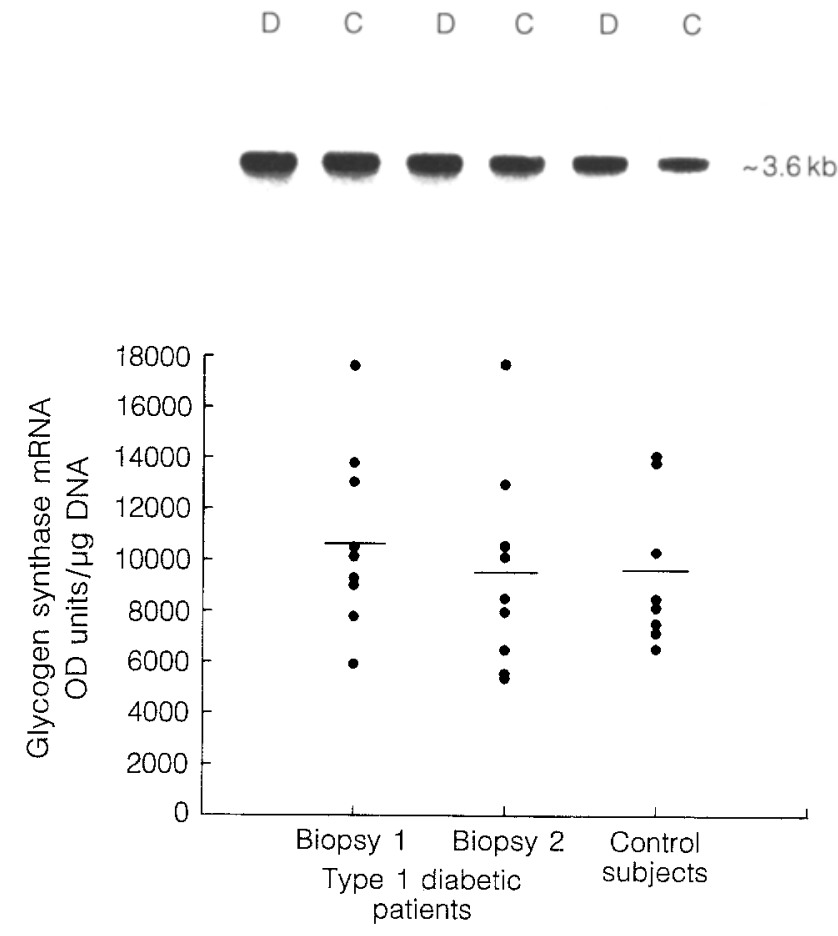

Fig.1. A Autoradiogram of Northern-blot analysis of glycogen synthase mRNA levels in vastus lateralis muscle from Type 1 diabetic patients (D) and control subjects (C). The blot is representative of 17 subjects (nine diabetic patients and eight control subjects) (upper panel). Quantitation with densitometry of slotblots of glycogen synthase mRNA levels expressed relative to total DNA content of muscle showed no differences between the groups (lower panel). Biopsy 1 denotes Type 1 diabetic patients before 24-h intensified insulin therapy. Biopsy 2 denotes Type 1 diabetic patients after 24 -h intensified insulin therapy. B Autoradiogram of immunoblotting analysis of glycogen synthase protein levels in vastus lateralis muscle from Type 1 diabetic patients (D) before (biopsy 1) and after intensive insulin therapy (biopsy 2) and from control subjects (C) who are characterized in Subjects and Methods. The blot is representative of $15 \mathrm{sub}$ jects (nine diabetic patients and six control subjects) (upper panel). Quantitation with densitometry showed no differences between the groups (lower panel). OD, optical density; kb, kilobase

crease in the $\mathrm{FV}_{0.1}$ of $\mathrm{GS}$ in diabetic patients $(p=0.03)$. The latter data were comparable to results obtained in control subjects (Table 1). The G6P concentration that half-maximally stimulates $\mathrm{GS}\left(\mathrm{A}_{0.5}\right)$ was $45 \%$ higher in diabetic patients before aggressive insulin therapy $(p=0.01)$ and decreased significantly following $24-\mathrm{h}$ intensified insulin therapy $(p=0.02)$ to a level which was similar to results obtained in control subjects.

$P F K$ activity. No differences between diabetic patients and control subjects in PFK activity were found at any concentration of F6P, either before or after intensive insulin therapy $(p>0.05)$. The calculated maximal
B
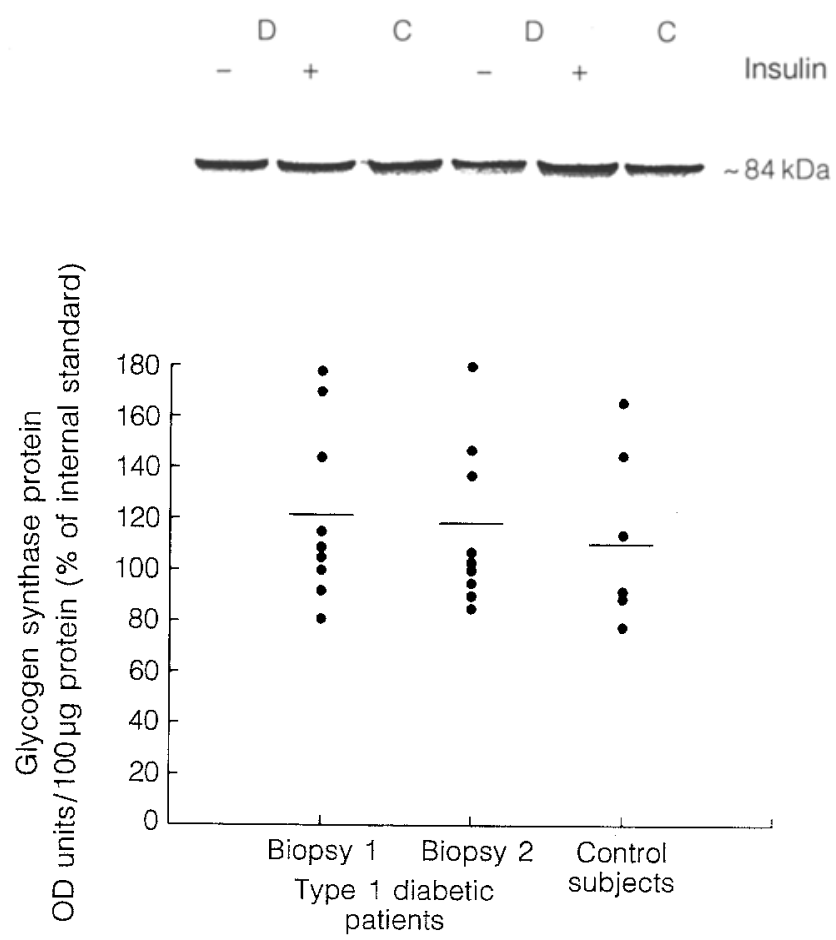

PFK activities were similar in diabetic patients and control subjects (Table 2).

$H K$ activity. To investigate if low activity of GS in patients with poorly-controlled Type 1 diabetes could be secondary to decreased HK activity and thereby to low concentrations of intracellular G6P we measured HK activity in muscle biopsies from diabetic and control subjects. No statistically significant differences were found before $(p>0.05)$ or after intensive therapy $(p>0.05)$ when compared to control subjects, either at a low $(0.11 \mathrm{mmol} / \mathrm{l})$ or at a high glucose concentration $(11.0 \mathrm{mmol} / \mathrm{l})$ (Table 2$)$.

\section{GS and PFK mRNA levels}

GS $m R N A$. In Northern blot analysis, the GS cDNA recognized a single transcript of 3.6 kilobases $(\mathrm{kb})$ in both groups (Fig.1 A, upper panel). When slot blots were loaded with equal amounts of total RNA per slot, the abundance of the specific GS mRNA showed a 2-3 fold variation within each group. However, neither before (20968 \pm 1411 optical density [OD] units/ $\mu \mathrm{g}$ total RNA $[n=9]$ ) nor after intensive insulin therapy $(18177 \pm 1649$ OD units/ $\mu g$ total RNA $[n=9])$ did the level of GS-specific mRNA differ from the level which was found in control subjects $(21301 \pm 1179$ OD units/ $\mu \mathrm{g}$ total RNA [ $n=8]$ ). It may, however, be physiologically more relevant to normalize the results relative to the DNA content of muscle (Table 3), assuming that equal concentrations of DNA reflect the same number of multinucleated muscle cells. Using the 
A

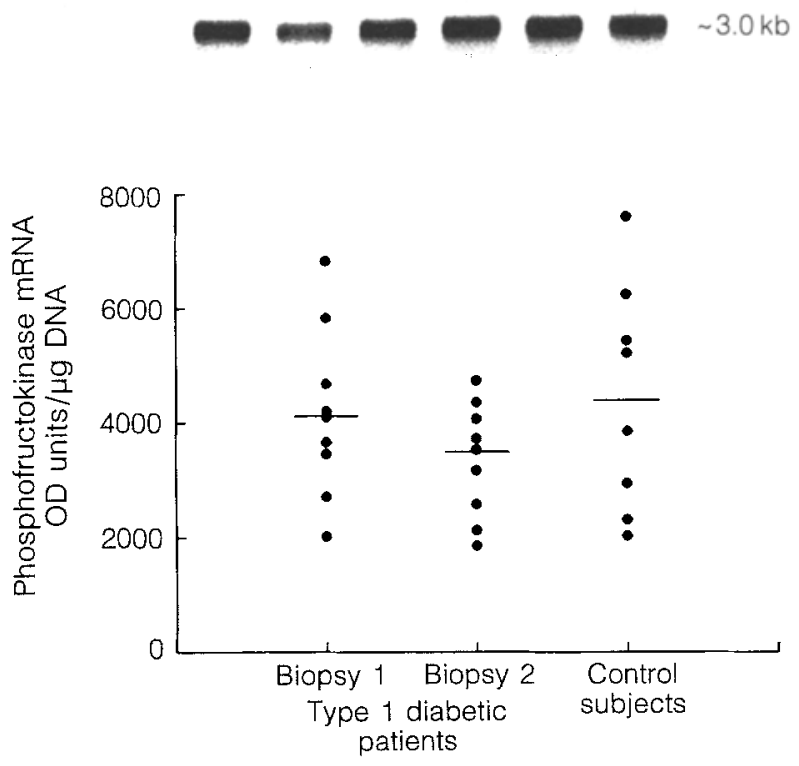

Fig.2. A Autoradiogram of Northern-blot analysis of phosphofructokinase mRNA levels in vastus lateralis muscle from Type 1 diabetic patients (D) and control subjects (C). The blot is representative of 17 subjects (nine diabetic patients and eight control subjects) (upper panel). Quantitation with densitometry of slotblots of phosphofructokinase mRNA levels expressed relative to total DNA content of muscle showed no differences between the groups (lower panel). First biopsy denotes Type 1 diabetic patients before 24-h intensified insulin therapy. Second biopsy denotes Type 1 diabetic patients after 24-h intensified insulin therapy. B Autoradiogram of immunoblotting analysis of phosphofructokinase protein levels in vastus lateralis muscle from Type 1 diabetic patients (D) before (biopsy 1 ) and after intensive insulin therapy (biopsy 2) and from control subjects (C) who are characterized in Subjects and Methods. The blot is representative of 15 subjects (nine diabetic patients and six control subjects) (upper panel). Quantitation with densitometry showed no differences between the groups (lower panel). OD, optical density; kb, kilobase

latter approach the findings were similar (Fig.1A, lower panel). No correlations were found between levels of GS mRNA and GS protein in either group.

PFK $m R N A$. Northern blotting showed that the PFK cDNA recognized a single transcript of $3.0 \mathrm{~kb}$ in both groups (Fig. $2 \mathrm{~A}$, upper panel). The level of specific PFK mRNA showed a 2-4 fold variation but no difference was seen in the level of PFK $m$ RNA between the groups, either before or after intensified therapy. When expressing the results per DNA, the findings were similar (Fig. 2 A, lower panel). No correlations were found between levels of PFK mRNA and PFK protein in either group.
B
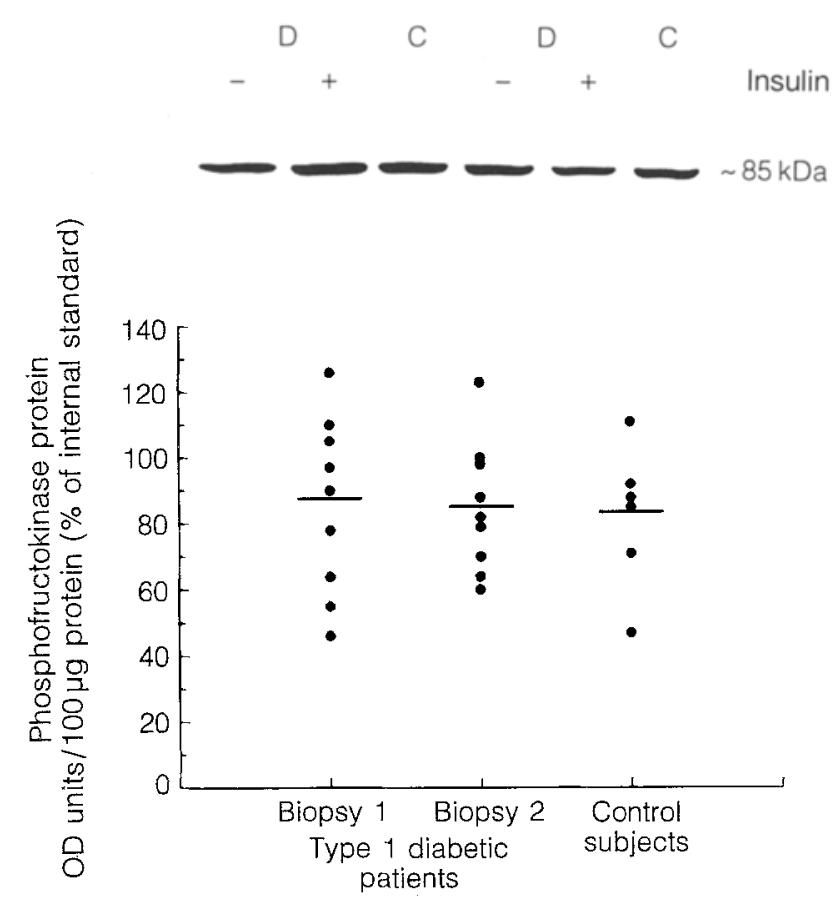

\section{GS and PFK immunoreactive protein levels}

The amount of GS and PFK immunoreactivities in homogenates from human skeletal muscle was quantitated by immunoblotting using antipeptide antisera specific for GS and PFK. In all participants a single band of $84 \mathrm{kDa}$ and of $85 \mathrm{kDa}$ was identified for GS and PFK immunoreactive proteins, respectively (Fig. 1B and Fig. 2B). Densitometric scanning of autoradiograms showed no difference between the groups in the relative levels of GS or PFK protein before intensive insulin therapy when results were adjusted for equal amounts of protein. GS: $114 \pm 14$ ( $n=6$ control subjects) vs $122 \pm 12$ OD units $/ 100 \mu \mathrm{g}$ protein (\% of internal standard) ( $n=9$ diabetic patients) (NS) (Fig. 1B) and PFK: $82 \pm 9$ ( $n=6$ control subjects) vs $88 \pm 9$ OD units $/ 100 \mu \mathrm{g}$ protein (\% of internal standard) ( $n=9$ diabetic patients) (NS) (Fig. 2B). After insulin therapy similar results were obtained, but still no differences were found between control subjects and diabetic patients. Expressing the GS and PFK immunoreactivities per muscle DNA did not change the interpretation of the results. No correlations were found between levels of GS protein and total GS activity or between levels of PFK protein and maximal PFK enzyme activity in either group.

Due to shortage of muscle tissue we were unable to measure the gene expression of hexokinase in the present protocol. 


\section{Discussion}

We have examined whether short-term appropriate insulinization of patients with long-term Type 1 diabetes in poor metabolic control has any impact on the expression of the rate-limiting enzyme in muscle glucose storage, GS, and the rate-limiting enzyme in muscle glycolysis, PFK. Comparing Type 1 diabetic patients and healthy control subjects we found that a reduced allosterical activation of GS by G6P in muscle of diabetic patients in poor metabolic control occurs in the presence of normal total GS activity and normal levels of GS mRNA and immunoreactive protein. Furthermore, changes in serum insulin within the physiological range with a 2.8-fold increase over a 24 -h period did not contribute to the acute regulation of total GS activity and GS mRNA and immunoreactive protein abundance in muscle but normalized the muscle GS activation in diabetic patients. Hence, the present data suggest that the impaired glycogen synthesis of skeletal muscle from Type 1 diabetic patients in poor metabolic control [1-3] is caused by post-translational modifications of the GS enzyme which may be secondary to metabolic derangements $[3,7]$. This interpretation of results is compatible with the study of Vuorinen-Markkola et al. [28] demonstrating that $24 \mathrm{~h}$ of hyperglycaemia induces a severe impairment of whole-body non-oxidative glucose metabolism in Type 1 diabetic patients.

However, recently, it was reported that the rate-limiting defect for glucose disposal in skeletal muscle of Type 1 diabetic patients is at the level of glucose transport since no accumulation of intracellular glucose or glucose metabolites was detected during hyperglycaemia [10]. It should be noted that in these experiments hyperglycaemia was induced under conditions of supraphysiological insulinaemia where insulin-sensitive enzymes such as GS and pyruvate dehydrogenase are also highly stimulated [29]. Thus, glucose metabolism may have been enhanced to the same extent as glucose transport. Moreover, in another study of Type 1 diabetic patients [30] intracellular accumulation of free glucose and G6P was found during a hyperglycaemic clamp, indicating that the rate-limiting step in skeletal muscle glucose metabolism in Type 1 diabetic patients is located distal to glucose phosphorylation. Based on experimental data in the available literature we cannot rule out the possibility that impaired insulin-stimulated glucose transport of peripheral tissues contributes to the insulin-resistant glucose utilization in Type 1 diabetic subjects. Thus, Yki-Järvinen et al. [31] have shown that the response of GLUT 4 mRNA to a supraphysiological insulin challenge is diminished in muscle from Type 1 diabetic patients, whereas we [32] found that changes in serum insulin levels within the physiological range had no impact on GLUT 4 mRNA and protein expression in muscle tissue from patients with poorly-controlled Type 1 diabetes. We still do not know whether the intrinsic activity and/or transloca- tion of GLUT 4 glucose transporters are impaired in skeletal muscle from these patients.

In patients with Type 2 (non-insulin-dependent) diabetes, in vivo measurement of the muscle content of $\mathrm{G} 6 \mathrm{P}$ by ${ }^{31} \mathrm{P}$ nuclear magnetic resonance during a hyperglycaemic-hyperinsulinaemic clamp showed a decrease in both $\mathrm{G} 6 \mathrm{P}$ and in non-oxidative glucose metabolism when compared with healthy control subjects [33]. These findings are consistent with a defect in glucose transport and/or phosphorylation inducing a secondary reduction in the rate of muscle glycogen synthesis [33]. Also, in the present study of Type 1 diabetic subjects the diminished allosterical activation of GS by G6P might be due to a relatively low concentration of G6P in muscle of diabetic patients. Unfortunately, the shortage of muscle tissue did not allow us to measure the content of G6P. However, we did measure the total activity of $\mathrm{HK}$ which was similar in muscle biopsies from diabetic subjects and healthy volunteers suggesting that it is unlikely that muscles of Type 1 diabetic patients under the chosen experimental conditions are characterized by reduced concentrations of G6P.

The rate-limiting defect in glucose disposal to peripheral tissue of Type 1 diabetic patients could obviously be located to the formation of glycogen in skeletal muscle $[1,30]$, a process which is allosterically stimulated by G6P and covalently stimulated by insulin. The stimulatory effect of G6P at physiological concentrations seems to be specific for GS and is most likely due to a conformational change of the enzyme which facilitates its dephosphorylation [34]. One possible explanation for the impaired allosterical activation of GS by G6P in patients with poorly-controlled Type 1 diabetes might be the occurence of intervening metabolic factors which inhibit the physiological interaction between GS and G6P. The elevated circulating level of NEFA might be considered an intervening factor since studies in normal man have shown that intravenous infusion of triglycerides and heparin causes a severe decrease in muscle GS fractional activity probably due to an increase in the muscle content of long-chain acyl-CoA inducing an inhibition of GS activity [35].

The reduced GS activation in the present study was restored to normal by intensified insulin treatment during a 24-h period coinciding not only with significant decreases in plasma levels of glucose and NEFA but also with a significant rise in serum insulin concentration. Insulin (in the absence of G6P) induces a covalent activation of GS by dephosphorylation processes $[36,37]$. Studies in rabbit skeletal muscle have demonstrated that GS is phosphorylated on nine serine residues in vitro by means of five or more protein kinases. Phosphate release from GS in response to insulin occurs mainly from one tryptic peptide in the highly phosphorylated $\mathrm{C}$ terminal end of the enzyme containing three phosphoserine residues, termed $3 \mathrm{a}$, $3 \mathrm{~b}$ and $3 \mathrm{c}[36,38]$. Therefore, insulin activates GS 
either by inhibiting glycogen synthase kinase-3, i. e. the protein kinase that specifically phosphorylates sites $3 \mathrm{a}-\mathrm{c}$ [39] or by stimulating protein phosphatase- 1 , the principal enzyme dephosphorylating GS $[40,41]$. Using reverse phase HPLC of complete tryptic digests of purified muscle GS, it has been demonstrated in some [37, 39] but not all [36] studies that the phosphate content of sites $3 \mathrm{a}-\mathrm{c}$ and the neighbour site 2 is selectively elevated in alloxan-induced, hypoinsulinaemic diabetic rabbits. These abnormalities were reversible by insulin treatment $[37,39]$. Altogether, it may be suggested that the complete normalization of GS activation of muscle from Type 1 diabetic patients following aggressive therapy may be related to the amelioration of intervening factors for the allosterically induced conformational changes as well as an enhanced covalent activation by insulin. In support of this notion is another study of Type 1 diabetic patients who were investigated before and after 6 weeks of continuous subcutaneous insulin infusion. After near normalization of metabolic control in these diabetic subjects total as well as percent active GS enzyme activity was similar to values achieved in healthy control subjects [1].

Glycolysis, particularly oxidative glycolysis (glucose oxidation) represents the other major fate of whole body glucose disposal. The flux through this pathway is reduced in Type 1 diabetic patients when assessed at both low and high plasma insulin levels [10]. Moreover, from studies of insulinopenic streptozotocin diabetic rats, muscle PFK activity has been shown to be decreased possibly due to a decrease in total available enzymatically active protein and to unfavourable levels of intracellular PFK inhibitors, for instance citrate[14]. In these animal studies insulin treatment completely normalized PFK activity suggesting that the diminished PFK activity was due to insulin deficiency [14]. In our study the fasting serum insulin levels were similar between groups before intensive insulin treatment and this may be the reason why we found a normal PFK activity in muscle from Type 1 diabetic patients. However, in vivo PFK activity of muscle could obviously have been decreased in the diabetic patients if intracellular citrate concentrations were actually increased. Since muscle tissue citrate concentrations were not measured, it is not possible to address this question. Furthermore, no differences between the diabetic patients and control subjects were demonstrated in the total immunoreactive mass of human muscle PFK either before or after intensive insulin therapy. Cloning and sequencing of the PFK cDNA from human skeletal muscle [42] also made it possible to examine the pretranslational regulation of PFK. Northern-blot analysis revealed a $3.0 \mathrm{~kb}$ transcript, the size of which was unaffected by diabetes. Quantitation of PFK mRNA by slot-blot analysis did not show any significant difference between the groups and changes in serum insulin within the physiological range did not possess any short-term regulatory impact.
Pyruvate dehydrogenase (PDH) is another key enzyme in glycolysis and in normal man muscle PDH is stimulated by intravenous insulin infusion [29]. Reduction in glucose oxidation as demonstrated in Type 1 diabetes [10] might be related to decreased PDH activity in skeletal muscle from these patients. However, in a study of Type 1 diabetic patients, who were treated with conventional insulin therapy or with continuous subcutaneous insulin infusion, total as well as percent active PDH activity was normal in both the fasting state and following $4 \mathrm{~h}$ of insulin infusion when compared to control subjects [1]. A confounding factor in the protocol was the fact that basal enzyme analysis was achieved and performed after an overnight period of euglycaemia which was maintained by intravenous insulin infusion. Therefore, it cannot be ruled out that this experimental protocol may have modified the muscle PDH activity [1].

Acknowledgements. This investigation was supported by grants from Torben Frimodt and Alice Frimodt's Foundation, Søster and Verner Lipperts Foundation, Danish Diabetes Association, Nordisk Insulin Foundation and Institute of Experimental Clinical Research, Aarhus University. The technical assistance of Ms A. Forman, B.Mottlau, H. Fjordvang and L.Blak is gratefully acknowledged.

\section{References}

1. Kruszynska YT, Petranyi G, Home PD, Taylor R, Alberti KGMM (1986) Muscle enzyme activity and insulin sensitivity in type 1 (insulin-dependent) diabetes mellitus. Diabetologia 29: 699-705

2. Del Prato S, Nosadini R, Tiengo A, et al. (1983) Insulinmediated glucose disposal in type 1 diabetes: evidence for insulin resistance. J Clin Endocrinol Metab 57: 904-910

3. Beck-Nielsen H, Richelsen B, Hother-Nielsen O, Heding LG, Schwartz Sørensen N (1984) Improved in vivo insulin effect during continuous subcutaneous insulin infusion in patients with IDDM. Diabetes 33: 832-837

4. Yki-Järvinen H, Koivisto VA (1986) Natural course of insulin resistance in type 1 diabetes. N Engl J Med 315:224-230

5. Lager I, Lönnroth P, Von Schenck H, Smith U (1983) Reversal of insulin resistance in type 1 diabetes after treatment with continuous subcutaneous insulin infusion. BMJ 287 : 1661-1664

6. Nankervis A, Proietto J, Aitken P, Alford F (1984) Impaired insulin action in newly diagnosed type 1 (insulin-dependent) diabetes mellitus. Diabetologia 27: 497-503

7. Pedersen O, Beck-Nielsen H (1987) Insulin resistance and insulin-dependent diabetes mellitus. Diabetes Care 10: 516523

8. Bak JF, Jacobsen UK, Jørgensen FS, Pedersen O (1989) Insulin receptor function and glycogen synthase activity in skeletal muscle biopsies from patients with insulin-dependent diabetes mellitus: effects of physical training. J Clin Endocrinol Metab 69: 158-164

9. Pedersen O, Hjøllund E (1982) Insulin receptor binding to fat and blood cells and insulin action in fat cells from insulindependent diabetics. Diabetes 31: 706-715

10. Yki-Järvinen H, Sahlin K, Ren JM, Koivisto VA (1990) Localization of rate-limiting defect for glucose disposal in 
skeletal muscle of insulin-resistant type 1 diabetic patients. Diabetes 39: 157-167

11. DeFronzo RA, Jacot E, Jequier E, Maeder E, Wahren J, Felber JP (1981) The effect of insulin on the disposal of intravenous glucose. Results from indirect calorimetry and hepatic and femoral venous catherization. Diabetes 30: 1000-1007

12. Cohen P (1986) Muscle glycogen synthase. In: Boyer PD, Krebs EG (eds) The enzymes. Harcourt Brace Jovanovich Orlando San Diego New York Austin Boston London Sydney Tokyo Toronto, pp 461-497

13. Uyeda K (1979) Phosphofructokinase. In: Meister A (ed) Advances in enzymology and related areas of molecular biology. Vol 48. John Wiley \& Sons, New York Chichester Brisbane Toronto pp 193-244

14. Bauer BA, Younathan ES (1984) Decreased phosphofructokinase activity in skeletal muscle of diabetic rats. Clin Physiol Biochem 2: 137-145

15. Katz A, Raz I, Spencer MK, Rising R, Mott DM (1991) Hyperglycemia induces accumulation of glucose in human skeletal muscle. Am J Physiol 260: R698-R703

16. Bak JF, Pedersen O (1990) Exercise-enhanced activation of glycogen synthase in human skeletal muscle. Am J Physiol 258: E957-E963

17. Beutler E (1971) Phosphofructokinase. Red cell metabolism: a manual of biochemical methods. E Beutler (ed) Grune \& Stratton, Inc, New York pp 42-44

18. Easterby JS, Qadri SS (1977) Hexokinase type II from rat skeletal muscle. Meth Enzymol 90: 11-15

19. Chomczynski P, Sacchi N (1986) Single-step method of RNA isolation by acid guanidinium thiocyanate-phenol-chloroform extraction. Ana Biochem 162: 156-159

20. Pedersen O, Bak JF, Andersen PH, et al. (1990) Evidence against altered expression of GLUT1 or GLUT4 in skeletal muscle of patients with obesity or NIDDM. Diabetes 39:865870

21. Labarca C, Paigen K (1980) A simple rapid and sensitive DNA assay procedure. Ann Biochem Exp Med (Calcutta) 102: $344-351$

22. McKinney M, Parkinson A (1987) A simple, non-chromatographic procedure to purify immunoglobulins from serum and ascites fluid. J Immunol Methods 96: 271-278

23. Andersen I, Hannibal S (1983) Analytical and economical optimization of a glucose method with immobilized enzymes. J Autom Chem 5: 188-192

24. Heding LG (1972) Determination of total serum insulin (IRI) in insulin-treated diabetic patients. Diabetologia 8: 260-266

25. Heding LG (1975) Radioimmunological determination of human C-peptide in serum. Diabetologia 11: 541-548

26. Mortensen HB (1980) Quantitative determination of hemoglobin $\mathrm{A} 1 \mathrm{C}$ by thin layer isoelectric focusing. J Chromatogr 182: $325-333$

27. Itaya K, Michio U (1965) Colorimetric determination of free fatty acids in biological fluids. J Lipid Res 6: 16-20

28. Vuorinen-Markkola H, Koivisto VA, Yki-Järvinen H (1992) Mechanisms of hyperglycemia-induced insulin resistance in whole body and skeletal muscle of type 1 diabetic patients. Diabetes 41: 571-580
29. Mandarino LJ, Wright KS, Vertity LS, et al. (1987) Effects of insulin infusion on human skeletal muscle pyruvate dehydrogenase, phosphofructokinase and glycogen synthase. J Clin Invest 80: 655-663

30. Vaag A, Hother-Nielsen O, Skøtt P, Andersen P, Richter EA, Beck-Nielsen H (1992) Effect of acute hyperglycemia on glucose metabolism in skeletal muscles in IDDM patients. Diabetes 41: 174-182

31. Yki-Järvinen $\mathrm{H}$, Vuorinen-Markkola $\mathrm{H}$, Koranyi LI, et al. (1992) Defect in insulin action on expression of the muscle/adipose tissue glucose transporter gene in skeletal muscle of type 1 diabetic patients. J Clin Endocrinol Metab 75: 795-799

32. Andersen PH, Vestergaard H, Lund S, et al. (1993) The effect of intensive insulin therapy on insulin-regulatable glucose transporter (GLUT4) expression in skeletal muscle in type 1 diabetes. Diab Med 10:699-703

33. Rothman DL, Shulman RG, Shulman GI (1992) ${ }^{31} \mathrm{P}$ nuclear magnetic resonance measurements of muscle glucose-6phosphate. Evidence for reduced insulin-dependent muscle glucose transport or phosphorylation activity in non-insulindependent diabetes mellitus. J Clin Invest 89: 1069-1075

34. Villar-Palasi C (1991) Substrate specific activation by glucose 6-phosphate of the dephosphorylation of muscle glycogen synthase. Biochim Biophys Acta 1095: 261-267

35. Boden G, Jadali F, White J, et al. (1991) Effects of fat on insulin-stimulated carbohydrate metabolism in normal men. J Clin Invest 88: 960-966

36. Parker PJ, Caudwell FB, Cohen P (1983) Glycogen synthase from rabbit skeletal muscle; effect of insulin on the state of phosphorylation on the seven phosphoserine residues in vivo. Eur J Biochem 130: 227-234

37. Sheorain VS, Juhl H, Bass M, Soderling TR (1984) Effects of epinephrine, diabetes, and insulin on rabbit skeletal muscle glycogen synthase. J Biol Chem 259: 7024-7030

38. Dent P, Lavoinne A, Nakielny S, Caudwell FB, Watt P, Cohen $P(1990)$ The molecular mechanism by which insulin stimulates glycogen synthesis in mammalian skeletal muscle. Nature 348: 302-308

39. Sheorain VS, Ramakrishna S, Benjamin WB, Soderling TR (1985) Phosphorylation of sites 3 and 2 in rabbit skeletal muscle glycogen synthase by multifunctional protein kinase (ATP-citrate lyase kinase). J Biol Chem 260: 12287-12292

40. Strảlfors P, Hiraga A, Cohen P (1985) The protein phosphatase involved in cellular regulation: purification and characterisation of the glycogen-bound form of protein phosphatase-1 from rabbit skeletal muscle. Eur J Biochem 149: 295303

41. Ingebritsen TS, Stewart AA, Cohen P (1983) The protein phosphatases involved in cellular regulation: measurement of type-1 and type-2 protein phosphatases in extracts of mammalian tissues; an assessment of their physiological roles. Eur J Biochem 132: 297-307

42. Sharma PM, Reddy GR, Vora S, Babior BM, McLachlan A (1989) Cloning and expression of a human muscle phosphofructokinase cDNA. Gene 77: 177-183 